\title{
PELAKSANAAN MANAJEMEN PESERTA DIDIK PADA MAN BERINGIN KOTA SAWAHLUNTO
}

\author{
Junaidi \\ Kepala Seksi Pendidikan Agama Islam \\ Kantor Kementerian Agama Kota Sawahlunto \\ Koresponden: Perumahan Asam J ao Indah Subarang Koto Baru Solok \\ Email: J unaidi@gmail.com
}

\begin{abstract}
This study was aimed at describing the implementation of the management of learners at $M A N$ Beringin Kota Sawahlunto. This study was related to qualitative descriptive to prove the actual object (study phenomena) and was compared from the theory. The findings showed that the implementation of learners' management generally had been accomplished in accordance with the function of management.
\end{abstract} For the management of counseling, it was not optimal because it does not have the program and facility.

Keywords: Management, Learners, MAN Beringin

\section{PENDAHULUAN}

Manajemen peserta didik adalah salah satu aspek dari manajemen sekolah/ madrasah. Menurut Imron (2011: 6) manajemen peserta didik atau pupilpersonel administration adalah "usaha pengaturan terhadap peserta didik mulai dari peserta didik itu masuk sekolah sampai dengan mereka lulus”. Manajemen peseta didik memiliki peran yang strategis dari sekian banyak manajemen sekolah/madrasah, karena semua aktifitas manajemen pada sekolah/madrasah baik yang berkenaan dengan manajemen kurikulum, manajemen sarana dan prasarana, manajemen keuangan dan lainya, akan bermuara atau diarahkan agar peserta didik mendapatkan layanan pendidikan yang baik. Di samping itu peserta didik dapat memiliki hak yang sama untuk mendapatkan layanan pendidikan.

Masalah yang melatarbelakangi penelitian ini adalah belum optimalnya pelaksanaan manajemen peserta didik di MAN Beringin Kota Sawahlunto. Berdasarkan observasi awal yang peneliti lakukan diperoleh data antara lain sebagai berikut.

Tabel 1. Jumlah Peserta Didik Pada MAN Beringin Kota Sawahlunto Tiga Tahun Terakhir

\begin{tabular}{|c|l|c|c|c|c|c|c|l|}
\hline No & \multicolumn{1}{|c|}{ T.Pelajaran } & $\begin{array}{c}\mathrm{XI} / \\
\text { IA }\end{array}$ & $\begin{array}{c}\mathrm{X} 2 / \\
\text { IS }\end{array}$ & $\begin{array}{c}\mathrm{XI} / \\
\text { IA }\end{array}$ & $\begin{array}{c}\mathrm{XI} / \\
\text { IS }\end{array}$ & $\begin{array}{c}\text { XII/ } \\
\text { IA }\end{array}$ & $\begin{array}{c}\text { XII/ } \\
\text { IS }\end{array}$ & JML \\
\hline 1 & $2012 / 2013$ & 22 & 22 & 9 & 16 & 9 & 7 & 85 \\
\hline 2 & $2013 / 2014$ & 26 & 26 & 19 & 22 & 9 & 14 & 116 \\
\hline 3 & $2014 / 2015$ & 23 & 24 & 19 & 36 & 21 & 19 & 142 \\
\hline
\end{tabular}


Berdasarkan tabel di atas, jumlah peserta didik pada tahun pelajaran 2014/2015 adalah paling tinggi dibandingkan dengan jumlah peserta didik pada dua tahun sebelumnya, yaitu 142 orang siswa/siswi. Namun, jumlah tersebut belum memenuhi daya tampung madrasah sebanyak 32 orang siswa untuk masing-masing rombongan belajar yang ada. Berdasarkan temuan melalui wawancara dengan Asrin, S.Ag pada tanggal 12 September 2015 diungkapkan bahwa "terdapat dua buah rombongan belajar (IPA dan IPS), masing-masing rombongan belajar tersedia 32 pasang kursi dan bangku dengan muatan masing-masing untuk 1 orang siswa”. Jadi idealnya untuk masing-masing rombongan belajar adalah 32 orang siswa/siswi.

Tabel di atas juga menerangkan bahwa terdapat dua buah rombongan belajar yaitu kelas XI/IA dan kelas XII/IS dengan jumlah hanya 19 orang siswa/siswi. Siswa/siswi pada rombongan belajar tersebut belum memenuhi standar minimal jumlah siswa/ siswi untuk tingkat SLTA, sebagaimana ditetapkan oleh Peraturan Menteri Pendidikan Nasional Nomor: 060/U/2002, "standar minimal jumlah siswa/siswi untuk masing-masing rombongan belajar pada tingkat SLB adalah 5 orang, tingkat SD adalah 10 orang, dan tingkat SLTA adalah 20 orang". Jumlah minimal siswa/siswi sebagaimana diatur dalam Permendiknas tersebut juga diberlakukan dalam peraturan Depdiknas tahun 2013/2014 terkait dengan penentuan jam mengajar guru.

Di samping itu juga berdasarkan pengamatan peneliti masih terdapat sebagian perilaku siswa yang belum mencerminkan akhlak yang baik seperti merokok di lingkungan madrasah, membolos dan tidak mengikuti kegiatan full day. Kasus-kasus tersebut bertentangan dengan visi dan misi madrasah yaitu melaksanakan kegiatan pembinaan keagamaan dan menerapkan nilai-nilai Islam dalam kehidupan seharihari.

\section{PENGERTIAN MANAJEMEN PESERTA DIDIK}

Banyak istilah yang dipakai untuk menyebut peserta didik misalnya, pada Taman Kanak-Kanak disebut anak didik (PP. Nomor 27 Tahun 1990). Selanjutnya pada pendidikan dasar dan menengah disebut siswa (PP. Nomor 28 dan 29 Tahun 1990). Sementara pada perguruan tinggi disebut mahasiswa (PP. Nomor 30 Tahun 1990), juga mempunyai sebutan-sebutan lain seperti murid, subjek didik, anak didik, pelajar dan sebagainya. Walaupun berbeda dalam sebutan namun mempunyai maksud yang sama yaitu peserta didik adalah mereka yang sedang mengikuti program pendidikan 
pada suatu sekolah/madrasah atau jenjang pendidikan tertentu. Nizar (2011) mendeskripsikan lima kriteria peserta didik yaitu 1) peserta didik bukanlah miniatur orang dewasa tetapi memiliki dunianya sendiri; 2) peserta didik memiliki periodesasi perkembangan dan pertumbuhan; 3) peserta didik adalah makhluk Allah yang memiliki perbedaan individu baik disebabkan oleh faktor bawaan maupun faktor lingkungan di mana ia berada; 4) peserta didik memiliki dua unsur utama jasmani dan rohani, unsur jasmani memiliki daya fisik dan unsur rohani memiliki daya akal, hati nurani, dan nafsu; dan 5) peserta didik adalah manusia yang memiliki potensi atau fitrah yang dapat dikembangkan dan berkembang secara dinamis.

Dengan demikian, manajemen peserta didik dapat dikatakan sebagai suatu proses pengaturan atau pengelolaan terhadap peserta didik (dengan berbagai kebutuhan, kompetensi, keunikan, serta dimensidimensi yang dimilikinya) yang sedang mengikuti program pendidikan pada sekolah/madrasah atau jenjang pendidikan tertentu. Proses pengaturan atau pengelolaan peserta didik tersebut dilakukan melalui empat fungsi manajemen yaitu planning, organizing, actuating, dan controlling. Hal senada juga diungkapkan oleh Knezevich (1961) bahwa manajemen peserta didik atau pupil personnel administration adalah suatu layanan yang memusatkan perhatian pada pengaturan, pengawasan dan layanan siswa di kelas dan di luar kelas seperti: pengenalan, pendaftaran, layanan individu seperti pengembangan seluruh kemampuan, minat, bakat, kebutuhan sampai ia matang.

\section{Tujuan Manajemen Peserta Didik}

Menurut Imron (2011) tujuan manajemen peserta didik adalah mengatur kegiatan-kegiatan peserta didik agar kegiatankegiatan tersebut menunjang proses belajar mengajar di sekolah, yaitu 1) meningkatkan pengetahuan, ketrampilan dan psikomotor peserta didik; 2) menyalurkan dan mengembangkan kemampuan umum, bakat dan minat peserta didik; 3) menyalurkan aspirasi, harapan, dan memenuhi kebutuhan peserta didik; 4) dengan terpenuhinya 1, 2 dan 3 di atas diharapkan peserta didik dapat mencapai kebahagiaan dan kesejahteraan hidup, dapat belajar dengan baik dan tercapai cita-cita mereka.

\section{Prinsip-Prinsip Manajemen Peserta Didik}

Prinsip manajemen peserta didik adalah hal-hal yang harus dipedomani dalam mengelola peserta didik. Menurut Imron (2011) terdapat enam prinsip yang perlu dipedomani dalam mengelola peserta didik 
yaitu 1) harus dipandang sebagai bahagian dari manajemen sekolah/madrasah; 2) haruslah mengandung makna pendidikan; 3) harus diupayakan untuk mempersatukan peserta didik; 4) harus dipandang sebagai upaya pengaturan dalam rangka mengembangkan peserta didik; 5) harus mampu mendorong kemandirian peserta didik; dan 6) haruslah selalu diupayakan bersifat fungsional bagi kehidupan peserta didik.

\section{Pendekatan Manajemen Peserta Didik}

Menurut Yeager (1994) terdapat dua pendekatan yang dapat digunakan dalam manajemen peserta didik yaitu pendekatan kuantitatif (the quantitative approach) dan pendekatan kualitatif (the qualitative approach). Pendekatan kuantitatif menitikberatkan pada aspek administratif dan birokratik lembaga pendidikan. Wujud dalam manajemen peserta didik yang operasional adalah mengharuskan kehadiran peserta didik secara mutlak di sekolah, memperketat presensi, penuntutan disiplin yang tinggi, menyelesaikan tugas-tugas yang diberikan kepadanya, pendekatan ini teraksentuasi pada upaya agar peserta didik mampu.

Pendekatan kualitatif diarahkan agar peserta didik senang. Asumsi pendekatan ini adalah apabila peserta didik telah senang dan sejahtera maka mereka dapat belajar dengan baik serta senang. Karena itu sekolah/ madrasah perlu menciptakan kondisi serta iklim yang kondusif.

\section{RUANG LINGKUP MANAJEMEN PESERTA DIDIK}

\section{Perencanaan Peserta Didik}

Pembinaan peserta didik pada sekolah/madrasah haruslah diarahkan kepada pencapaian tujuan dan fungsi pendidikan nasional. Menurut Undang Undang Nomor 20 Tahun 2003 Bab II Pasal 3 pendidikan nasional berfungsi mengembangan kemampuan dan membentuk watak serta kepribadian bangsa yang bermartabat dalam rangka mencerdaskan kehidupan bangsa, bertujuan untuk mengembangkan potensi peserta didik agar menjadi manusia yang beriman dan bertaqwa, berakhlak mulia, sehat, berilmu, cakap, kreatif, serta bertanggung jawab. Berdasarkan rumusan fungsi serta tujuan pendidikan nasional tersebut dapat dirumuskan beberapa program pembinaan peserta didik yaitu 1) pembinaan keimanan dan ketaqwaan peserta didik; 2) pembinaan budi pekerti luhur; 3) pembinaan kepemimpinan; 4) pembinaan kreatifitas dan kewirausahaan; 5) kesehatan jasmani 
dan rohani; 6) pembinaan seni budaya; dan 7) bela Negara.

Dalam rangka mencapai tujuan dan fungsi pendidikan nasional maka perencanaan peserta didik haruslah melalui langkah-langkah yang sistematis. Imron (2011) menyebutkan, terdapat beberapa langkah yang harus ditempuh dalam merumuskan perencanakan peserta didik yaitu "forecasting, objectif, policy, programming, produre, schedule, bugetting".

\section{Penerimaan Peserta Didik}

Penerimaan peserta didik baru adalah kegiatan manajemen, sebagaimana dijelaskan Imron (2011) tahap-tahap penerimaan peserta didik baru adalah a) tahap planning, pada tahap ini perlu pengkajian terhadap faktor kondisional madrasah (berapa daya tampung sekolah, berapa murid yang tinggal kelas, bagaimana sarana dan prasarana sekolah, berapa tenaga guru yang ada), dan penetapan sistem penerimaan peserta didik; b) tahap organizing, secara umum tahap ini adalah proses pembagian tugas, sehingga tugas-tugas PPDB yang telah direncanakan dapat dibagi habis; c) tahap Actuating, pada tahap ini terdapat beberapa agenda yang dilakukan yaitu pengumuman penerimaan peserta didik, pendaftaran calon peserta didik, seleksi peserta didik, penentuan calon peserta didik, pengumuman peserta didik, pendaftaran ulang, dan mencatat peserta dalam Buku Induk. Tahap controlling adalah evaluasi terhadap perencanaan peserta didik.

\section{Kedisiplinan Peserta Didik}

Kehadiran peserta didik di sekolah/ madrasah adalah hal yang sangat penting karena berlangsungnya proses pendidikan menghendaki keterlibatan langsung antara pendidik dan peserta didik. Dengan demikian perlu adanya pengaturan terhadap kehadiran dan ketidakhadiran peserta didik di sekolah/ madrasah. Adapun yang dimaksud dengan kehadiran peserta didik di sekolah/madrasah (school attandence) menururt Imron (2011: 82) adalah kehadiran dan keikutsertaan peserta didik secara fisik dan mental terhadap aktifitas sekolah/madrasah pada jam-jam efektif di sekolah/madrasah.

\section{Bimbingan dan Konseling}

Menurut Mortensen dan Schmuller (1965), seperti yang dikutip oleh Ibrahim Bapadal bahwa pelaksanaan pendidikan di sekolah perlu melibatkan bimbingan yang terarah. Pengertian bimbingan 
menurut Peraturan Pemerintah Nomor 29 tahun 1990, Bab X pasal 27 berbunyi, "bimbingan adalah bantuan yang diberikan kepada siswa dalam rangka upaya menemukan pribadi, mengenal lingkungan, dan merencanakan masa depan, bimbingan diberikan oleh guru pembimbing".

\section{a. Personalia bimbingan}

Menururt Sujanto (2007) personalia atau tenaga bimbingan di tingkat sekolah/madrasah adalah kepala sekolah/ madrasah, wakil kesiswaan, guru bimbingan, guru mata pelajaran, wali kelas, dan pengawas.

a. Komponen program bimbingan

Menurut Sukardi (2009), Komponen program bimbingan dan konseling di sekolah mencakup pelayanan dasar, pelayanan responsif, perencanaan individu, dan dukungan sistim. a) pelayanan dasar, ini diberikan kepada seluruh peserta didik melaui penyiapan pengalaman terstruktur secara klasikal atau kelompok. Tujuan pemberian layanan dasar ini adalah agar peserta didik memiliki pemahaman tentang diri dan lingkungan (pendidikan, pekerjaan, social, budaya dan agama). Kemudian agar peserta didik mampu mengembangkan ketrampilanya, mampu memahami masalah dan mengambil keputusan yang tepat dan mampu mengembangkan diri dalam rangka tujuan hidupnya; b) pelayanan responsif, ini diberikan kepada peserta didik yang membutuhkan bantuan segera, sebab kalau tidak akan mengganggu perkembanganya. Konseling individu, konseling kritis, konsultasi dengan orang tua, guru dan alih tangan kasus adalah ragam pelayanan yang dapat dilakukan dalam layanan responsif ini. Tujuan dari layanan responsif adalah membantu peserta didik agar dapat memenuhi kebutuhanya dan mampu memecahkan masalah yang dialaminya. Untuk mengetahui masalah tersebut dapat dilakukan assessment dan analisis perkembangan peserta didik melalui angket, konsultasi atau wawancara, observasi, daftar hadir, legger, psikotes dan daftar masalah peserta didik, atau alat ungkap masalah lainya; c) perencanaan individu adalah bantuan kepada peserta didik agar mereka mampu merumuskan dan melakukan aktifitas yang berkaitan dengan 
perencanaan masa depan atas dasar kelebihan dan kekurangan dirinya, serta pemahaman atas peluang yang ada pada lingkungan. Kegiatan orientasi, informasi, konseling individu rujukan pustaka, kolaborasi dan advokasi diperlukan dalam pelayanan ini; d) dukungan system, merupakan komponen pelayanan tidak langsung kepada klien seperti kegiatan manajemen, tatakerja, infrastruktur (tekhnologi informasi) dan sebagainya.

b. Organisasi Siswa Intra Sekolah (OSIS)

Salah satu bentuk organisasi peserta didik di sekolah/madrasah adalah organisasi siswa intra sekolah (OSIS). Tujuan OSIS adalah untuk meningkatkan iman dan taqwa, menjunjung tinggi kebudayaan nasional, meningkatkan persepsi, apresiasi dan kreasi seni sebagai dasar pembentukan kepribadian luhur, serta mempertinggi semangat kebangsaan. Struktur OSIS antara lain pembina (kepala sekolah/ madrasah, guru, waka kesiswaaan, perwakilan kelas dan pengawas); perwakilan kelas; dan Pengurus Osis antara lain Ketua, Wakil ketua, Sekretaris, Bendahara, Bidang- bidang seperti peningkatan iman dan taqwa, kehidupan berbangsa, pendidikan bela negara, kepribadian dan budi pekerti, ketrampilan dan kewirausahaan.

\section{METODE PENELITIAN}

Jenis penelitian ini bersifat kualitatif dengan metode deskriptif karena 1) dilaksanakan pada kondisi yang alamiah; 2) lebih bersifat deskriptif, sumber data utama dalam penelitian kualitatif adalah kata-kata dan tindakan, sehingga tidak menekankan pada angka; 3) lebih menekankan pada proses daripada produk atau outcome; 4) analisis data dilakukan secara induktif; dan 5) lebih menekankan makna (data dibalik yang teramati) (Sugiyono, 2007: 9). Dalam mengumpulkan data yang dibutuhkan, peneliti menggunakan teknik pengumpulan data wawancara dan studi dokumen. Analisis data dilakukan melalui 3 tahap, yaitu data reduction (reduksi data); data display (penyajian data); dan Conclusion Drawing/ Verification (Kesimpulan). Menurut Moleong, (2007: 307) aktivitas dalam analisis data kualitatif dilakukan secara interaktif dan berlangsung secara terus menerus pada setiap tahapan penelitian sehingga sampai tuntas, dan datanya sampai jenuh. 
HASIL PENELITIAN DAN PEMBAHASAN

Berdasarkan keterangan dari beberapa narasumber pada MAN Beringin Kota Sawahlunto dapat dikatakan bahwa secara umum pelaksanaan manajemen peserta didik yang mencakup, perencanaan peserta didik, disiplin peserta didik, penerimaan peserta didik, bimbingan dan konseling, dan organisasi peserta didik sudah terlaksana menurut empat fungsi manajemen, planning, organizing, actuating, dan controlling.

Pada tahap planning sudah ditetapkan tujuan atau sasaran untuk masing-masing program. Sebagaimana dijelaskan oleh Schermerhorn (2008: 450) perencanaan adalah proses menentukan tujuan, menetapkan tujuan kinerja spesifik, dan mengidentifikasi tindakan yang diperlukan untuk mencapainya.

Tahap organizing (pengorganisasian), sudah ada pembagian kerja yang baik dengan menempatkan orang-orang yang tepat untuk melaksanakan suatu pekerjaan. Sebagaimana dikatakan Koontz dan Weihrich (2002: 7) membentuk struktur untuk orang-orang yang akan mengisi sebuah organisasi. Sehubungan dengan itu, Ruky (2007: 9) mengatakan bahwa "mengorganisir adalah fungsi kritis untuk setiap manajer, mengorganisir melibatkan

44 Jurnal al-Fikrah, Vol. III, No. 1, Januari-Juni 2015 keputusan tentang bagaimana membagikan pekerjaan yang harus diselesaikan".

Tahap actuating (pelaksanaan), telah ada upaya pemimpin dalam membangkitkan semangat kerja para pegawainya atau pelaksana kegiatan. Sebagaimana dikatakan oleh Schermerhorn (2008:18) yaitu Actuating adalah proses membangkitkan antusiasme orang untuk bekerja keras dan upaya mereka untuk memenuhi rencana dan mencapai tujuan. Dengan memimpin, manager membangun komitmen untuk sebuah misi bersama, mendorong kegiatan mereka mencapai tujuan, dan pengaruh lain untuk melakukan pekerjaan mereka.

Tahap evaluating, merupakan upaya pemimpin dalam mengevaluasi suatu program kerja, mulai dari tahap perencanaan sampai pelaksanaan, dan setelah semua rangkaian kegiatan dilaksanakan. Hal tersebut sesuai dengan pendapat Ruky (2007: 45) yaitu metode pengawasan yang dapat dilakukan oleh seorang manager adalah pree-action control (pengawasan sebelum kegiatan), steering control (pengawasan saat kegiatan berlangsung), pengawasan pasca kegiatan (pengawasan setelah seluruh rangkaian kegiatan dilakukan).

Namun, pelaksanaan manajemen bimbingan dan konseling walaupun sudah terlaksana tetapi belum optimal. Hal ini 
dapat dilihat pada fungsi perorganisasian di mana MAN Beringin Kota Sawahlunto tidak memiliki guru BK, dan untuk melaksanakan program BK ditunjuk seorang guru. Tetapi karena tugas rangkap yang harus dilaksanakan akibatnya BK belum terlaksana dengan baik, belum ada program kerja yang terencana serta dukungan sarana dan prasrana yang memadai.

\section{KESIMPULAN}

Dari hasil pembahasan tersebut di atas dapat dikemukakan beberapa kesimpulan antara lain sebagai berikut.

1. Pelaksanaan manajemen peserta didik pada MAN Beringin Kota Sawahlunto secara umum sudah terlaksana dengan baik sesuai fungsi manajemen; dan

2. Pelaksanaan manajemen Bimbingan dan Konseling meskipun sudah terlaksana namun belum optimal, belum ada program kerja BK yang terencana, serta dukungan sarana dan prasarana BK yang memadai.

\section{SARAN}

Berdasarkan kesimpulan di atas, dapat disampaikan beberapa saran sebagai berikut.

1. Kepada Kementrian Agama Kota Sawahlunto agar mengangkat guru bimbingan dan koseling pada MAN
Beringin Kota Sawahlunto dan mengadakan worshop atau pelatihan bagi tenaga BK yang diangkat dari guru bidang studi;

2. Kepada Dinas Pendidikan Kota Sawahlunto diharapkan menerapkan aturan yang tegas tentang PPDB agar lebih meningkatkan dukungannya untuk terselenggaranya kegiatan bimbingan dan konseling di MAN Beringin Kota Sawahlunto; dan

3. Kepala madrasah beserta Komite dan pihak terkait lainya pada MAN Beringin Kota Sawahlunto perlu duduk bersama membicarakan segala sesuatu untuk terselenggaranya program bimbingan dan konseling.

\section{KEPUSTAKAAN ACUAN}

Imron, Ali. (2011). Manajemen Peserta Didik Berbasis Sekolah. Jakarta: Bumi Aksara.

Knezevich. (1961). Administration and Management. New York: Mc.Graw Hill.

Koonz, Harold dan Heinz Weihrich. (2002). Management a Global Persfective, New York: Mc.Graw Hill.

Moleong, Lexy, J, (2007). Metodologi Penelitian Kualitatif. Bandung: PT. Remaja Rosdakarya 
Nizar. (2011). Madrasah untuk Indonesia Masa Depan. Direktur Pendidikan Madrasah.

Peraturan Menteri Pendidikan Nasional Nomor: 060/U/2002

Peraturan Pemerintah Nomor 27 Tahun 1990

Peraturan Pemerintah Nomor 28 dan 29 Tahun 1990

Peraturan Pemerintah Nomor 30 Tahun 1990

Ruky, Ahmad S. (2007). Sukses Menjadi Manajer Profesional. Jakarta
Schermerhorn. (2008). Management Leading \& Colloboration In The Competitive Word. New York: McGraw-Hill

Sukardi. (2009). Visionary Leadership Menuju Sekolah Efektif. Jakarta: Bumi Aksara.

Sujanto, Bedjo. (2007). Manajemen Pendidikan Berbasis Sekolah. Jakarta.

Sugiyono. (2007). Memahami Penelitian Kualitatif. Bandung: CV. ALFABETA

Yeager. (1994). Adminstrasi Pendidikan. Jakarta. 